\title{
Benthic invertebrate fauna in Ashtoum El Gamil protected area (Lake Manzalah), Egypt.
}

\author{
S. S. I. Abdel Gawad ${ }^{1}$; A. M. Abdelhamid ${ }^{2}$; M. I. El-Barbary ${ }^{3}$ \\ and A. M. A. Mabrouk ${ }^{2}$ \\ 1-National Institute of Oceanography and Fisheries, Hydrobiology Lab., Egypt. \\ 2- Animal Production Department, Faculty of Agriculture, Al-Mansourah University, Egypt. \\ 3- National Institute of Oceanography and Fisheries, Fish Pathology Lab., Egypt
}

\section{ABSTRACT}

Macrobenthic and meiobenthic invertebrates' samples were collected seasonally during 2010 from five stations in Ashtoum El Gamil protected area which located in the north western part of Lake Manzalah. Macrobenthic community was found including fifteen species belonging to three groups. Of these, 11 Mollusca, 2 Arthropoda and 2 Annelida. Some of them have a freshwater origin and others have marine origin. Mollusca has been ranked the first position, constituting about $68.5 \%$ of the total population density (P. D.) of macrobenthic invertebrates, followed by Arthropoda and Annelida, constituting $28.7 \%$ and $2.8 \%$ respectively. The highest average standing crop was recorded in station 3. Macrobenthic fauna average value reached its maximum in winter in the whole area, while summer was the least productive season. Meiofauna community consisted of 3 main groups. Ostracoda was the first one, constituting $70.71 \%$ of the total population of meiofauna followed by Foraminifera (27 \%) and Nematoda (1.5\%). Meiofauna flourished during summer and spring in the area, while it reached its minimum levels during autumn and winter. Salinity and nature of the sediment were important factors affecting distribution and abundance of benthic invertebrates.

Key words: macrobenthic invertebrates, meiobenthic invertebrates, fauna, population density.

\section{INTRODUCTION}

Benthic invertebrates are those animals which spend all or most of their life in, on or near the bottom of any aquatic habitat. Information about benthos is required for studing productivity, fisheries and field population on which a long-term work on aquatic benthic communities and its possible indicator species can make a valuable contribution (Holme and mcintry, 1971). Benthos are classified by size into three categories a) macrobenthos are the larger, more visible, greater than $0.5 \mathrm{~mm}$ in size, such as polychaete worms, bivalves, echinoderms, sea anemones, sponges, turebellarians and larger crustaceans such as crabs and lobsters. b) meiobenthos are tiny benthos that are less than $0.5 \mathrm{~mm}$ but greater than $63 \mu \mathrm{m}$ in size such as are nematodes, foraminifrans, water beers and smaller crustaceans such as copepods and ostracodes. C) microbenthos are microscopic benthos that are less than $63 \mu \mathrm{m}$ in size. Some examples are bacteria, flagellates, amoebae and ciliates (Giere, 1993). Benthos feed mostly on detritis, plankton, algae and on eachother (Abdel Gawad, 2001). Macroinvertebrates feeding showed high selectivity towards the epiphytic diatoms (Abd El-Karim et al., 2009). The depth of water, temperature, salinity, and type of local substrates affect the ecology of benthos.

The present work aimed to study the community composition, distribution and seasonal variations of macrobenthic and meiobenthic invertebrates, with reference to 
the ambient variables in the area of Ashtoum El Ggamil Protected Area (Lake Manzalah).

\section{MATERIALS AND METHODS}

\section{1- Area of investigation}

Lake Manzalah is the largest of the Nile Delta lakes. It is located in the northeastern part of Egypt. It is bounded on the east by the Suez Canal and on the west by Damietta branch of the Nile and is separated from the Mediterranean Sea by a narrow sandy fringe at the north. The lake is connected to the Mediterranean Sea through a narrow channel (Boughaz ElGamil). The islands and reed beds divide the lake into well defined basins, each is known as Bahr, having more or less distinctive ecological conditions (Abdel-Baky et al., 1991). Samples were collected from Ashtoum El Gamil Protected Area which is located in the north western corner of Lake Manzalah, including new and old El Gamil inlets (Fig.1). Samples were collected from five stations, namely: station 1: inlet of El Gamil old in the north-east, station 2: inlet of El Gamil new in the north-west, station 3: Sea Kassab near to the middle, station 4: Sea Legan in the south-west and station 5: Sea Kur in the south-east, as illustrated in Fig. 2.

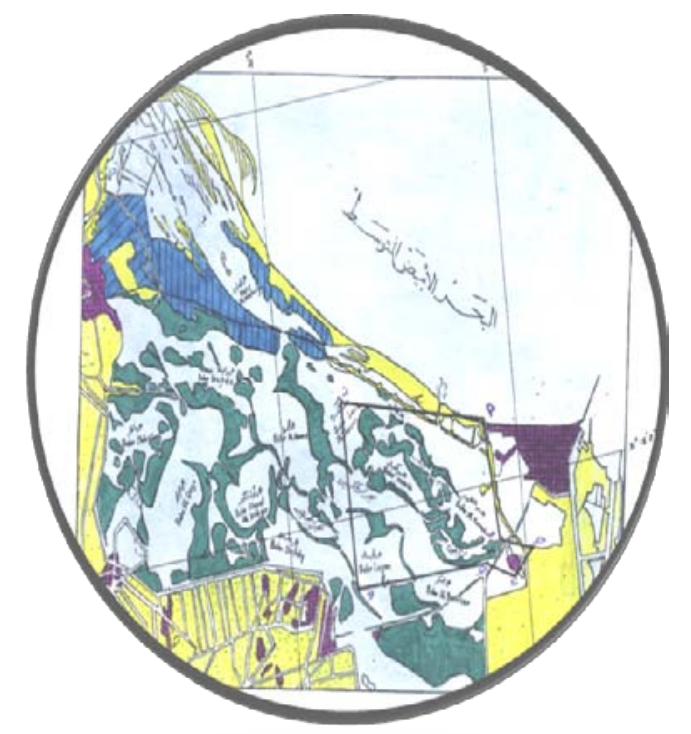

Fig. 1: Position of Ashtoum El Gamil Protected Area in Lake Manzalah.

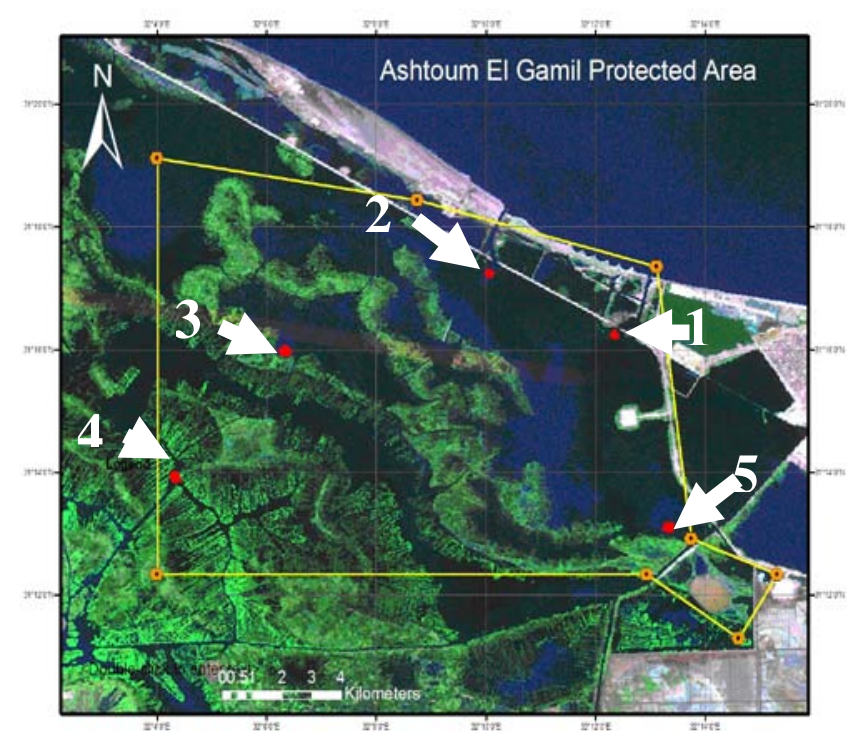

Fig. 2: Map of the study area, showing sampling stations (arrows). 


\section{2- Physicochemical parameters:}

The $\mathrm{pH}$, dissolved oxygen and salinity were measured seasonally in the field at the same time of sampling by using Digital Dissolved Oxygen Meter (DO-5509).

\section{3- Biological parameters \\ Sampling and treatment of samples: \\ Macrobenthic invertebrates}

Macrobenthic invertebrates' samples were collected seasonally during 2010 from the above five sampling localities covering the area of investigation, using Ekman Grab sampler (sampling area $250 \mathrm{~cm}^{2}$ ). The collected samples were washed through a screen of mesh size $500 \mu \mathrm{m}$, to remove any adhering bottom sediment and mud. The samples were stored in a plastic jars with $10 \%$ formalin solution. Each Jar was labeled with the relevant data. In the laboratory, samples were washed again in a net of $500 \mu \mathrm{m}$ mesh size diameter. By using Zoomsterio microscope, the animals were separated into groups and identified as much as possible to species level. Each species was counted and the population density was estimated and expressed as a number of organisms $/ \mathrm{m}^{2}$.

\section{Meiobenthic invertebrates}

Sampling of meiobenthic fauna was performed at the same five localities and during the same period of macrobenthos sampling. Samples were collected by using Ekman Grab (opening area of $250 \mathrm{~cm}^{2}$ ). At each site, an area of $33.17 \mathrm{~cm}^{2}$ was taken from the upper sediment surface. The samples were stained with Rose Bengal $(1 \mathrm{~g} / \mathrm{L})$ and preserved in $4 \%$ formalin solution. In Laboratory, the stained samples were passed through two sieves, the top one with a mesh opening of $500 \mu \mathrm{m}$ (captured macrofauna) and the bottom one with a mesh of $63 \mu \mathrm{m}$. Animals retained in the sediment in the lower sieve were considered as meiofauna. These samples were diluted to $100 \mathrm{ml}$ and few drops of Rose Bengal were added. From each sample, three sub samples ( $1 \mathrm{ml}$ each) were examined under a dissecting microscope for sorting and identification to the species or higher taxa level. The population density was calculated and expressed as a number of organisms $/ 10 \mathrm{~cm}^{2}$.

\section{RESULTS}

\section{Physicochemical parameters}

Temperature of the water followed the corresponding value of air temperature. Water temperature reached its maximum in summer and decreased gradually until it reached its minimum in winter. The water in the area lies at the alkaline side; the maximum value of $\mathrm{pH}$ (8.91) was recorded in station 1 during summer and winter, while the minimum one (7.07) was recorded in station 5 during autumn (Table 1). As shown from Fig. 3, the concentration of dissolved oxygen reached its maximum value (12.6) in station 1 during winter, while the minimum (7.7) was recorded in station 1 during summer. It was found that the average value of dissolved oxygen reached its maximum in the whole area during winter. Salinity readings showed big differences among the stations in the area of investigation. Stations 1 and 2 had saline water, while Station 3 was brackish and stations 4, 5 were considered fresh water (Table 1). The bottom sediment of the area investigated was homogenous and consisted of clay, silt, sand and broken shells in a proportion varying from one station to another. Mud (silt and clay) was abundant in stations 1, 2, 3 while broken and dead shells, calcareous tubes of some species, as shells of Balanus were dominant in stations 4 and 5. 

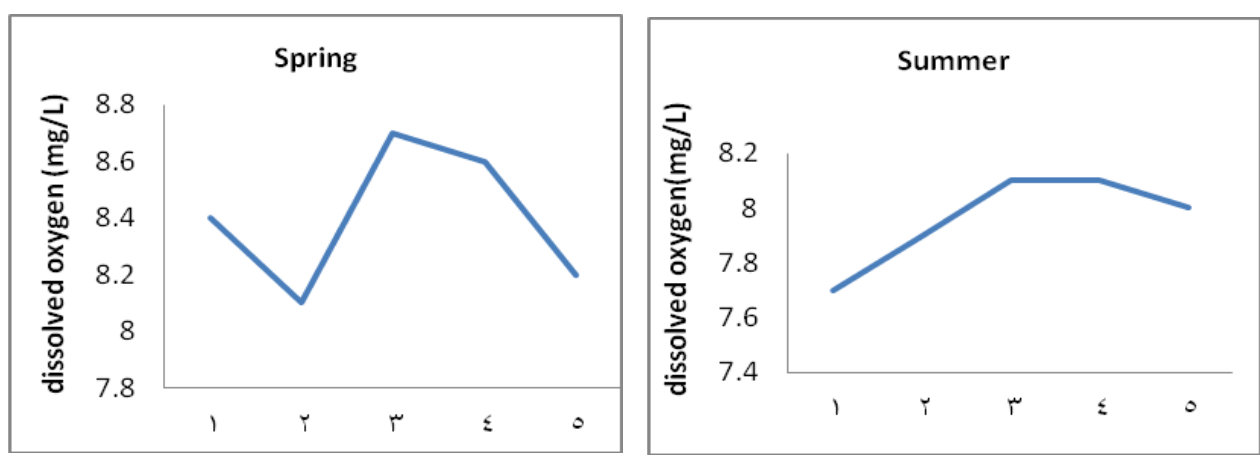

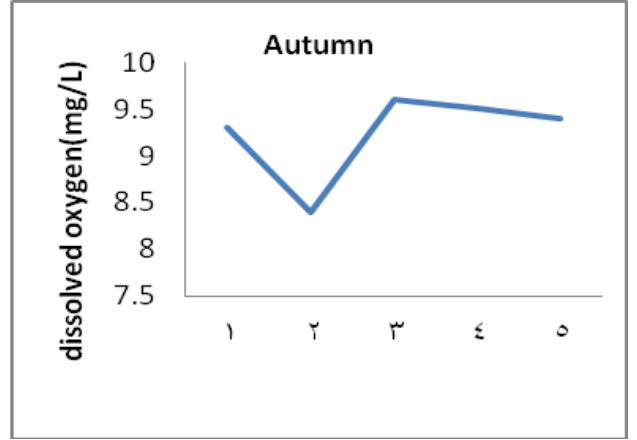

Stations

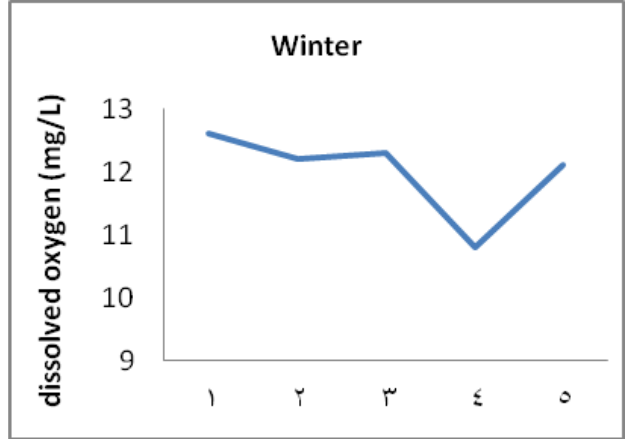

Stations

Fig. 3: Dissolved oxygen (mg/L) in the different stations during different seasons at Ashtoum El-Gamil.

Table 1: Seasonal records of $\mathrm{pH}$ values, dissolved oxygen $(\mathrm{mg} / \mathrm{L})$ and salinity $(\mathrm{g} / \mathrm{L})$ in the stations during the period of study at Ashtoum El-Gamil.

\begin{tabular}{|c|c|c|c|c|}
\hline Season & Station & $\mathrm{pH}$ & Oxygen & Salinity \\
\hline \multirow{4}{*}{ Spring } & 1 & 7.62 & 8.4 & 3.022 \\
\cline { 2 - 5 } & 2 & 7.79 & 8.1 & 36.220 \\
\cline { 2 - 5 } & 3 & 8.69 & 8.7 & 3.224 \\
\cline { 2 - 5 } & 4 & 8.52 & 8.6 & 3.015 \\
\cline { 2 - 5 } & 5 & 8.31 & 8.2 & 3.743 \\
\hline \multirow{4}{*}{ Summer } & 1 & 8.91 & 7.7 & 35.540 \\
\cline { 2 - 5 } & 2 & 7.79 & 7.9 & 36.948 \\
\cline { 2 - 5 } & 3 & 8.29 & 8.1 & 5.643 \\
\cline { 2 - 5 } & 4 & 7.80 & 8.1 & 4.047 \\
\cline { 2 - 5 } & 5 & 7.76 & 8.0 & 4.037 \\
\hline \multirow{5}{*}{ Autumn } & 1 & 7.80 & 9.3 & 8.91 \\
\cline { 2 - 5 } & 2 & 8.3 & 8.4 & 28.6 \\
\cline { 2 - 5 } & 3 & 7.62 & 9.6 & 3.46 \\
\cline { 2 - 5 } & 4 & 7.86 & 9.5 & 3.33 \\
\cline { 2 - 5 } & 5 & 7.07 & 9.4 & 3.47 \\
\hline \multirow{6}{*}{ Winter } & 1 & 8.91 & 12.6 & 3.232 \\
\cline { 2 - 5 } & 2 & 7.79 & 12.2 & 4.432 \\
\cline { 2 - 5 } & 3 & 8.29 & 12.3 & 3.488 \\
\cline { 2 - 5 } & 4 & 7.80 & 10.8 & 2.813 \\
\cline { 2 - 5 } & 5 & 7.76 & 12.1 & 2.835 \\
\hline
\end{tabular}

\section{Macrobenthos}

\section{Community composition:}

A total of fifteen species of macro invertebrates were identified in the collected samples during the period of investigation; including two Arthropoda, two Annelida and eleven Mollusca. Mollusca has been ranked the highest percentage of population density (P.D.) of community (68.5 \%) followed by Arthropoda (28.7 \%) 
and Annelida (2.8 \%) (Fig. 4). Some of species had a marine origin that was introduced into the lake through Boughaz El- Gamil.

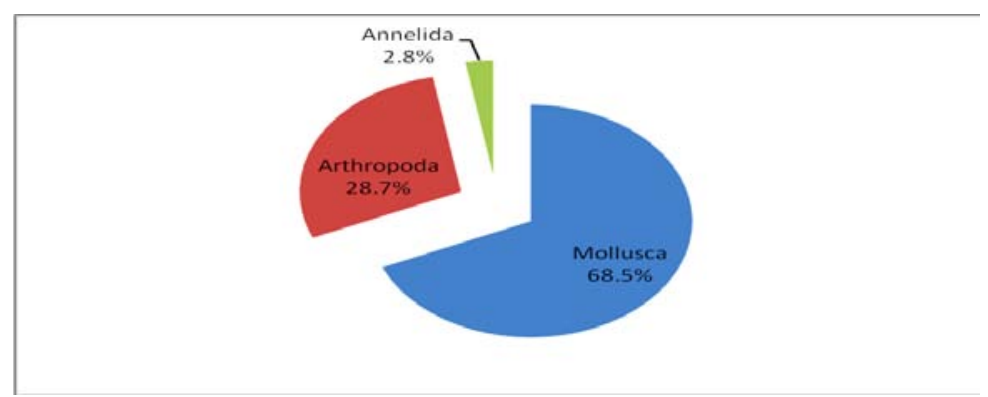

Fig. 4: Percentages of different groups of macrobenthic invertebrates in the investigated area.

The spatial and temporal distribution of total macrobenthic invertebrates:

The average P.D. of total macrobenthic invertebrates during the whole period of investigation in the whole area of study was 1568 organisms $/ \mathrm{m}^{2}$. The highest average P. D. (2860 organisms $/ \mathrm{m}^{2}$ ) was recorded in station 3 , while the lowest average P. D. (760 organisms $/ \mathrm{m}^{2}$ ) was recorded in station 4 (Table 2). Regarding seasonal variation, average P. D. of total macrobenthic invertebrates showed its maximum value in Winter and Autumn, while its minimum value were recored in Summer (Fig. 5).

Table 2: Seasonal variation of the population density of total macrofauna (organisms / $\mathrm{m}^{2}$ ) in sampled localities.

\begin{tabular}{|c|c|c|c|c|c|}
\hline Station & Spring & Summer & Autumn & Winter & Average \\
\hline 1 & 960 & 480 & 1040 & 2600 & 1270 \\
\hline 2 & 3560 & 600 & 840 & 2280 & 1820 \\
\hline 3 & 1280 & 1280 & 5280 & 3600 & 2860 \\
\hline 4 & 1240 & 600 & 600 & 600 & 760 \\
\hline 5 & 1280 & 720 & 1760 & 760 & 1130 \\
\hline Average & 1664 & 736 & 1904 & 1968 & 1568 \\
\hline
\end{tabular}

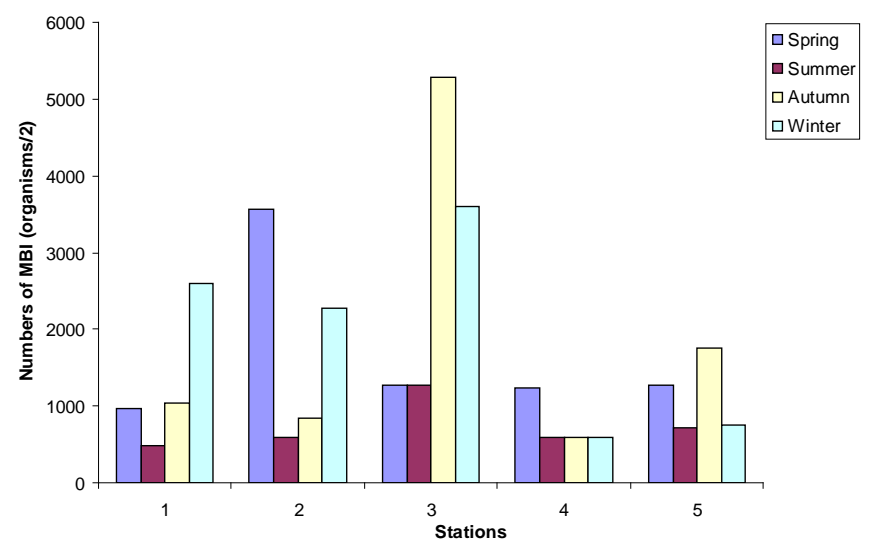

Fig. 5: Population densities of total MBI in different stations during the period of study.

\section{The spatial and temporal distribution of Mollusca:}

Mollusca was the most dominant group in the investigated area during this study. The average P.D. was 1074 organisms $/ \mathrm{m}^{2}$, constituting about $68.5 \%$ of the total macrobenthic fauna in the area. Station 3 was the most productive one with Mollusca, with an the average population density of 2760 organisms $/ \mathrm{m}^{2}$. The lowest P. D. (190 organisms/ $\mathrm{m}^{2}$ ) was found in station 1 . Regarding the temporal distribution, 
Mollusca reached its peak during autumn, when 1616 organisms / $\mathrm{m}^{2}$ were recorded. The lowest P. D. of Mollusca (584 organisms $/ \mathrm{m}^{2}$ ) was recorded during summer in the whole area (Fig. 6) that was represented by 8 species of gastropods and 3 species of bivalves. The species of gastropods were Pirenella conica, Melanoides tuberculata, Gyraulus erenbergi, Thiodoxis niloticus, Bulinus truncatus, Biomphalaria alexandrina, Semisalsa sp. and Physa acuta. The species of bivalves were Cerastoderma glucum, Corbicula consobrina, and Abra ovata. The most common molluscs in the area were Melanoides tuberculata, Cerastoderma glucum and Abra ovata, while Physa acuta was very rare in the area during this study. There were many broken and dead shells of these molluscs in the samples and did not taken into consideration in calculation.

The spatial and temporal distribution of Arthropoda:

Arthropoda formed about $28.7 \%$ of the total density of macrobenthic fauna in the area and was represented by two species only, namely: Balanas amphitrite and Chironomid larvae. The first was the most common species of the total macrobenthos. It was recorded in all sampling stations and constituted $26.8 \%$ of the total macrobenthic invertebrates and $93.3 \%$ of the arthropods in the area during this study. Balanas amphitrite was abundant, reaching its maximum density in stations $1 \& 2$, while it had a weak representation in other stations (3, 4 \& 5). This species was flourished during winter and decreased gradually until reaching its lowest P. D. during summer. Chironomid larvae appeared only an occasion in the whole area during the period of study (in stations $4 \& 5$ during winter with 40 and 80 organisms $/ \mathrm{m}^{2}$, respectively).

\section{The spatial and temporal distribution of Annelida:}

Annelida has been ranked the third position of the total P. D. of the study area, constituting $2.8 \%$. The distribution of this group showed weak abundance in all seasons comparing with Mollusca or Arthropoda (Fig. 6). It appeared only in stations $1,4,5$, and was absent totally in stations $2 \& 3$ during the whole period of study. It was represented by a polychaete Nereis diversicolor and an oligochaete Chaetogaster liminaei.

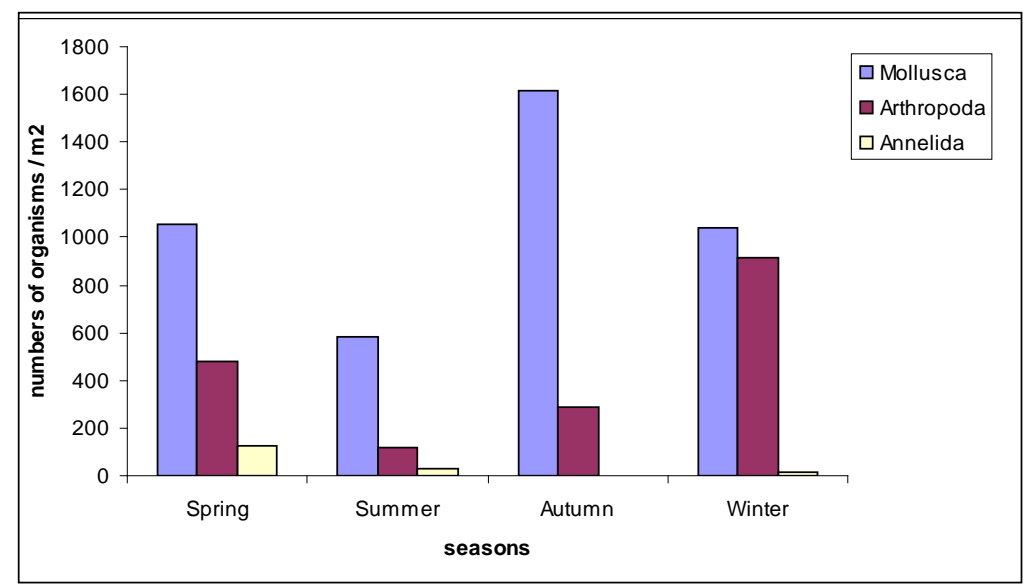

Fig. 6: seasonal variation of different groups of macrobenthic invertebrates in the investigated area.

\section{Meiobenthic invertebrates \\ Density and composition:}

Four major meiobenthic groups were recorded in the investigated area (Ostracoda, Foraminifera, Nematoda and Copepoda). Few numbers of small Annelida, and fish eggs were also recorded. Ostracoda was the most abundant group, 
constituting $70.71 \%$ of the total number of meiofauna in the area. Foraminifera, Nematoda and Copepoda followed Ostracoda, constituting about 27\%, 1.5\% and $0.31 \%$ of the total number of meiofauna in the area, respectively (Fig. 7 ). The average P. D. of meiofauna was 2803 organisms / $10 \mathrm{~cm}^{2}$ in the whole area. The highest number (9125 organisms/ $10 \mathrm{~cm}^{2}$ ) was recorded in station 3 while the lowest densities (1157.3 organisms / $10 \mathrm{~cm}^{2}$ and 1164.4 organisms $/ 10 \mathrm{~cm}^{2}$ ) were recorded in stations 5 and 2, respectively (Table 2).

Regarding seasonal variation, summer and spring were the most productive seasons, when the highest population densities (4652 organisms $/ 10 \mathrm{~cm}^{2}, 3176$ organisms $/ 10 \mathrm{~cm}^{2}$ ) were estimated, respectively. The lowest population density (1529 organisms / $10 \mathrm{~cm}^{2}$ ) was recorded during autumn (Table 4).

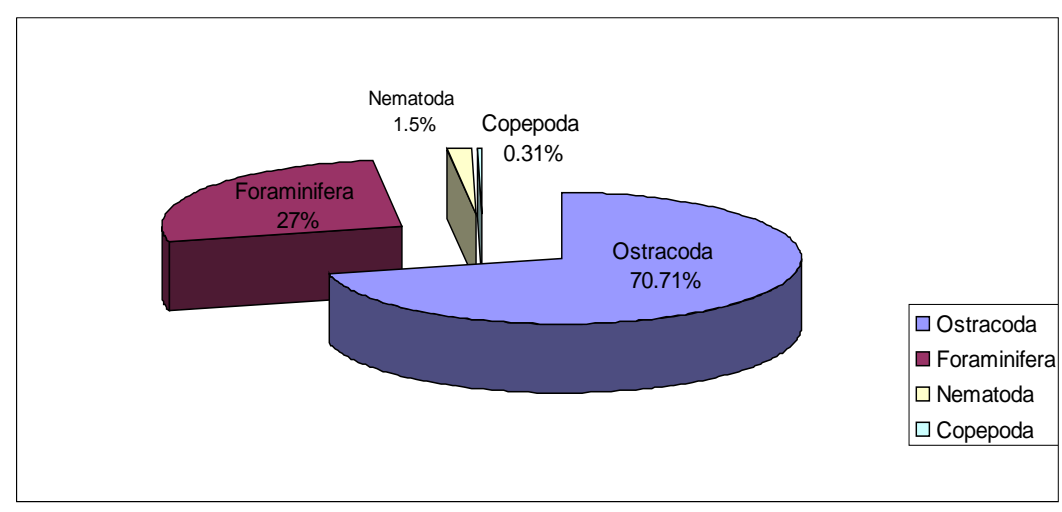

Fig. 7: Percentages of different groups of meiobenthic invertebrates in the investigated area.

Table 3: Average population density of meiofauna (organisms $/ 10 \mathrm{~cm}^{2}$ ) of different groups in sampled localities during the whole period of study

\begin{tabular}{|l|l|l|l|l|l|l|}
\hline Groups recorded & Station1 & Station 2 & Station 3 & Station 4 & Station 5 & Average \\
\hline Ostracoda & 1102.5 & 757 & 6585.9 & 745 & 717 & 1981.5 \\
\hline Foraminifera & 212.8 & 230.4 & 2517 & 450.6 & 420 & 766.2 \\
\hline Nematoda & 9.0 & 166 & 13 & 16.0 & 5.8 & 41.96 \\
\hline Small Annelida & - & 9.0 & - & 13.13 & 2.9 & 5.0 \\
\hline Copepoda & 11.7 & - & 8.8 & 11.6 & 11.7 & 8.8 \\
\hline Total & 1336 & 1162.4 & 9125.0 & 1223.2 & 1157.4 & 2803.5 \\
\hline
\end{tabular}

\section{The spatial and temporal distribution of major groups:}

\section{Ostracoda}

Ostracoda was the most common group of the meiobenthic invertebrates, and its average population density was 1981 organisms $/ 10 \mathrm{~cm}^{2}$. The highest P. D. was recorded in station 3 and the second peak was in station 1, while stations 2 , $4 \& 5$ were nearly similar. Concerning seasonal variation, a remarkable increase was recorded during summer and spring.

\section{Foraminifera}

The average P.D. of Foraminifera in the whole area was 766 organisms $/ 10 \mathrm{~cm}^{2}$. Station 3 was the most favorable ground in the investigated area, where its highest number (2517 organisms $/ 10 \mathrm{~cm}^{2}$ ) was recorded. The Lowest P. D. of Foraminifera was recorded in station 1. Foraminifera was represented by two species namely Ammonia sp. and Qunqueloculina sp., while summer was the most productive season for Foraminifera (Table 4). 


\section{Nematoda}

Nematoda occupied the third group in the investigated area after Ostracoda and Foraminifera, with an average number of 41 organisms $/ 10 \mathrm{~cm}^{2}$ during the period of study. The highest P. D. (166 organisms $/ 10 \mathrm{~cm}^{2}$ ) was recoded in station 2, while the lowest was in station 5. Nematoda flourished in winter and autumn. A sharp decrease in P. D. of nematode worms was shown in summer and spring (Table 4).

\section{Copepoda}

The average P. D. of copepods in the area was 8.7 organisms $/ 10 \mathrm{~cm}^{2}$. The numbers of Copepoda were nearly similar in stations $1,4 \& 5$ and it was missing totally from station 2 (Table 3 ). Copepoda was recorded during winter and spring and was absent from the area during summer and autumn (Table 4).

\section{Small Annelida}

Few numbers of small Annelida were recorded in the area, especially in stations 2, 4 \& 5 (Table 3), only during spring.

Table 4: Seasonal variation in population density (P. D.) of meiofauna (organisms $/ 10 \mathrm{~cm}^{2}$ ) of different groups in the whole area of investigation.

\begin{tabular}{|l|c|c|c|c|c|}
\hline Groups recorded & Spring & Summer & Autumn & Winter & Average \\
\hline Ostracoda & 2477.7 & 3376.3 & 1054.7 & 1017.5 & 1981.55 \\
\hline Foraminifera & 632.3 & 1274.0 & 408.3 & 750.14 & 766.19 \\
\hline Nematoda & 19.8 & 2.31 & 66.5 & 79.31 & 41.98 \\
\hline Small annelida & 19.8 & - & - & - & 5.0 \\
\hline Copepoda & 16.3 & - & - & 18.6 & 8.7 \\
\hline Total & 3175.9 & 4652.6 & 1529.5 & 1865.6 & 2803 \\
\hline
\end{tabular}

\section{DISCUSSION}

The importance of benthos lies in its position as a secondary producer in the food chain and any change in benthos is reflected on the growth and production of fish. Macroinvertebrate communities can be used as a good indicator for monitoring of ecosystem which can help in management and conservation of Lake Manzala (Fishar and Abdel-Gawad, 2009)

Temperature is known to have a direct effect on aquatic organisms and indirect effect through its influence on other environmental factors such as solubility of gases including oxygen (Abdel Gawad, 1993). The lowest P. D. of macrobenthic invertebrates (M.B.I.) was recorded in summer and the highest was recorded in winter. A strong negative correlation $(r=-0.87)$ was reported between P. D. of macrobenthic fauna and temperature of water during this study. This agrees with the observation of Abdel Gawad (2001) who recorded a negative correlation between temperature and total P. D. of M.B.I. in the River Nile at Helwan region. Changes in the temperature can also alter or completely inhibit the normal growth and spawning activities of some organisms (Hammerton, 1972 and Payne, 1986). Chironomid larvae disappeared during summer, spring, autumn. This may be due to the increase of water temperature which accelerates the development of larval stages, which agrees with Ramadan et al. (1998).

Difference in salinity in sampling sites can affect the distribution of some species such as Chatogaster limnaei which is a freshwater oligochaete that was recorded in stations 4 and 5, where salinity was too low (between 2.81 and $4.05 \mathrm{~g} / \mathrm{L}$ ). This agrees with Ahmed (1991) who stated that the salinity can determine species distribution and Khalil (1990) who stated that the diversity and distribution of organisms in Manzalah Lake are largely determined by salinity and reported also that, 
the mean abundance of benthic fauna ranged from 1494 to 2820 organisms $/ \mathrm{m}^{2}$. Mollusca species which were found in the area during this study are freshwater and marine in origin. Cerastoderma glucum, Abra ovata, Pirinela conica and Semisalsa sp. had marine origin, coming to the lake from the Mediterranean Sea. Fishar (1999) also recorded these species in Lake Manzalah. Bulinus truncatus, Biomphilaria alexandrina, Melanoides tuberculata, Corbicula consobrina dominated the low salinity sites in the study area and this agrees with Khalil (1990) who stated that these species are freshwater in origin.

Dissolved oxygen is one of the most important key factors in the metabolic processes of aquatic organisms. In this study, the highest average of dissolved oxygen (12 mg / L) was recorded in winter at the whole area. This may be due to water movement and low temperature which increase the solubility of oxygen in water (Delince, 1992). Dissolved oxygen affects positively on the abundance of total macrobenthic invertebrates. During this study, the highest P. D. of M.B.I. was recorded in winter.

Meiobenthic invertebrates community play an important role in the lakes food web. They serve as food for a variety of higher trophic levels and its high sensitivity to anthropogenic inputs making them excellent monitors for the study of pollution (Coull, 1999). Meiofauna in the investigated area showed its abundance peaks during summer and spring. This agrees with the results of Rudnick et al. (1985) who recorded high meiofaunal densities in some coastal marine ecosystem during summer. Fishar (1999 and 2000) recorded the highest densities of meiofauna during June and July; Abdel Gawad (2001 and 2007) recorded the highest number of meiofauna in the River Nile and El Serw Fish Farm respectively during summer. This may be attributed to the rapid rise in water temperature which was accompanied by abundanced food supply and increased rate of reproduction.

Ostracoda dominated the meiofauna in the area during this study and showed the highest peak in summer. This agrees with Smol et al. (1994) who stated that the abundance peak of Ostracoda was noted either in summer or spring and their minimum density was observed in winter.

Another factor that affected the distribution of meiofauna was the interaction between meiofauna and macrofauna. In this study, the lowest P. D. of macrofauna was recorded in summer when the P. D. of meiofauna was high. Moreover, there was a strong negative correlation $(r=-0.95)$ between P. D. of macro and P. D. of meiofauna in the area. Macrobenthic invertebrates decreased the number of meiobenthic invertebrates through mechanical disturbance of sediment (Bell, 1980) or due to predation (Wilson, 1991).

Sedimentological composition also affects the density of meiobenthos, where high densities of meiofauna were recorded in station 3 with sediment of higher mud content than other stations and the mud is related to high content of organic matter, in accordance with Coull (1988).

Free living nematodes were few in the investigated area. This may be due to high dissolved oxygen (from 7.7 to $12.6 \mathrm{mg} / \mathrm{L}$ ) and low contamination. This agrees with Bouwman et al. (1984) who stated that abundance of nematodes occurs in contaminated environment and they are more tolerant to low oxygen content than other taxa. Fishar and Abdel Gawad (2004) confirmed this result in Wadi El Rayyan Lakes. 


\section{REFERENCES}

Abdel-Baky, T. E., S. H. Hasan and K. A. H. Shallof (1991). Growth of Cichild species in Lake Manzala, Egypt. Bull. Fac. Sci., Mansoura Univ., 18: 442-453.

Abdel Gawad, S. S. (1993). Studies on macrobenthic invertebrates in El Serw Fish Farm region. M. Sc. thesis, Fac. Sci., Mansoura Univ., 203 p.

Abdel Gawad, S. S. (2001). Studies on benthic invertebrates of the Nile River at Helwan region. Ph. D. thesis, Fac. Sci., Mansoura Univ., 138 p.

Abdel Gawad, S. S. (2007). Some ecological aspects of meiobenthic community in El Serw Fish Farm (Dakahlyia, Egypt). Egypt. J. Aquat. Biol. \& Fish., 11(3): 589-601.

Abd El-Karim, M. S.; Fishar, M. R. and Abdel-Gawad, S. S. (2009). Epiphytic algae and macroinvertebrates communities of Myriophyllum spicatum Lemn and their Cascade in the littoral food Web of Lake Nasser, Egypt. Global Veterinaria, 3 (3): 165-177.

Ahmed, R. S. S. (1991). Studies of aquatic insects in Suez Canal region. M. Sc. thesis, Suez Canal Univ., 237 pp.

Bell, S. S. (1980). Meiofauna - macrofauna interactions in a high salt marsh habitat. Ecol. Monoger, 50: 487-505.

Bouwman, L. A.; Romeijn, K. and Admiral, W. (1984). On the ecology of meiofauna in an organically polluted estuarine mudflat. Estuarine, Coastal Shelf Sci., 19: 633-653.

Coull, B. C. (1988). Ecology of the marine meiofauna. In: R. P. Higgins \& H. Theil (eds.) Introduction to the Study of Meiofauna. Smithsonian Institute Press. Washington, D. C., London, pp: 18-38.

Coull, B.C. (1999). Role of meiofauna in estuarine soft bottom habits. Aust. J. Ecol., 24: 327-343.

Delince, G. (1992). The ecology of the fish pond ecosystem with special reference of Africa, Kluwer academic publisher, $230 \mathrm{pp}$.

Fishar, M. R. A. (1999). Distribution and abundance of benthic assemblages in El Gamil Basin (Lake El Manzalah, Egypt) (A) meiobenthos. Bull. Nat. Inst. Oceanogr. \& Fish. A.R.E., 25: 155-166.

Fishar, M. R. A. (2000). Composition, distribution and abundance of the meiobenthic fauna in Lake Qarun (Faiyom, Egypt).Egypt. J. Aquat. Biol. Fish., 4 (3): 45-60.

Fishar, M. R. and S. S. Abdel Gawad (2004). Ecologyof meiobenthic fauna in Wadi El-Rayyan Lakes, Fayoum, Egypt. J. Egypt. Ger. Soc. Zool., 45D: 23-35. Invertebrate Zoology and Parasitology,

Fishar, M. R. and Abdel Gawad, S. S. (2009). Macroinvertebrate communities associated with the Macrophyte Potamogeton pectinatus L. in Lake Manzalah, Egypt. Global Veterinaria, 3 (3): 239-247.

Giere, O. (1993). Meiobenthology .The microscopic fauna in aquatic sediments (ed.) Humburg Univ., 328 pp.

Hammerton, D. (1972). Studies of primary production in the Nile River. Thirteen Ann. Rep., 1965-1966, Hydrobiol. Res. Unit, Univ. Khartoum. p.p. 16-17.

Holme, N. A. and Mcintry, A. D. (1971). Methods for the study of Marine Benthos. Internatinal Biological Programme 7 Marylebone Road NWI. Blackwell Scientific Publications, Oxford and Edinburgh.

Khalil, M. T. (1990). Ecological studies on the bottom fauna of Lake Manzala, Egypt. Qatar University Science Journal, 10:215-225. 
Payne, A. I. (1986). The Ecology of Tropica Lakes and Rivers. John Wily \& Sons Chichester, New York, Tornoto, Brisbane and Singapore, 300 pp.

Ramadan, Sh. E.; Kheiralla, A. M. and Abdel Salam, Kh. M. (1998). Benthic communities in the Nile River, Egypt 1- Aquatic stages of Insecta. Proceeding of the $8^{\text {th }}$ Intern. Conf. on: Environmental protection is a must, 5-7, May, 1998. Egypt, pp. 178-189.

Rudnick,D. K.; Elmagren, R. and Frithsen, J. B. (1985). Meiofauna prominence and benthic seasonality in a costal marine ecosystem. Oecologia, 7: 157-168.

Smol N.; Willems, K. A.; Govaere, J. C. R. and Sandee, A. J. J. (1994). Composition, distribution and biomass of meiobenthos in the Oasteschelde estuary (SW Netherlands). Hydrobiol., 282/283: 197-217.

Wilson, W. H. (1991). Competition and predation in marine soft sediment communities. Ann. Rev. Ecol. Syst., 21: 221-241.

\section{ARABIC SUMMARY}

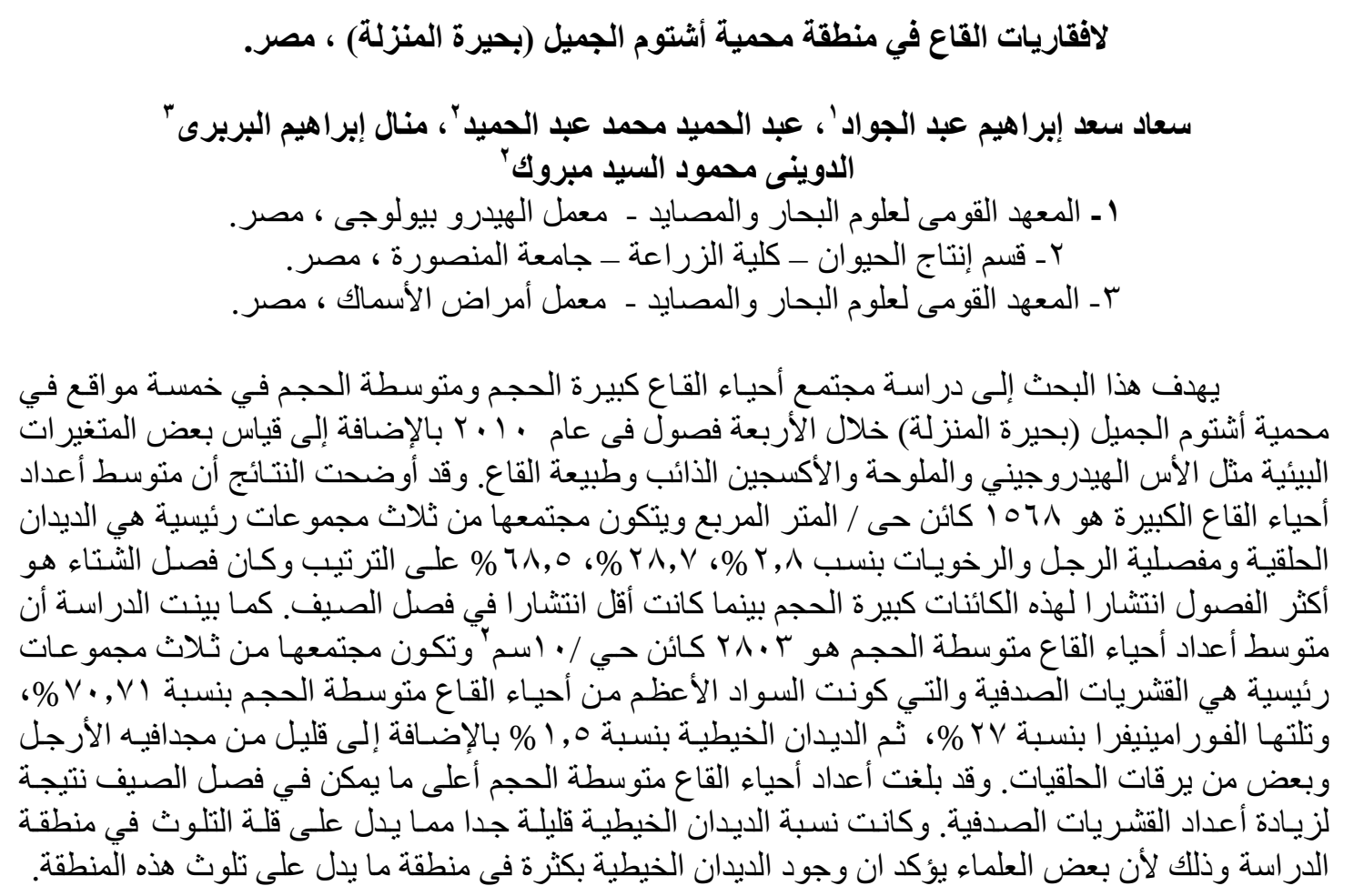

